\title{
Automobila: desafio sozio-teknikoa
}

The car: a socio-technical challenge

Andoni Eizagirre · aeizagirre@mondragon.edu

MONDRAGON UNIBERTSITATEA

Recibido: 18/03/2016

Aceptado: 31/05/2016

\section{Laburpena}

Automobilaren sistema osagai fisikoek, teknikoek eta humanoek osatzen dute. Baina sistema heldutasun egoera batera iritsita, osagaien arteko simetria galdu egiten da. Automobilak traiektoria, autonomia eta bulkada zehatza hartu ditu, osagaien malgutasuna galdu da, eta agente humanoen askatasun-gradua murriztu da. Azken hamarkadetan mugikortasun motorizatuaren egonkortzea gertatu da. Gainera, bizitza estiloak, ingurune soziala eta lurraldearen antolaketa ere automobilaren beharretara moldatu dira. Artikulu honetan mugikortasun motorizatuak Gipuzkoan izan duen bilakaera egiaztatuko da, eta ikuspegi sozio-teknikoarekin konprometituz, bilakaera esplikatu eta garraio jasangarri baterako iradokizunak egingo dira.

Hitz gakoak: automobila - teknologia - ikuspegi sozio-teknikoa - berrikuntza - jasangarritasuna

\section{Abstract}

The system of the automobile includes physical, technical, and human components, but as the system matures, the symmetry among components is lost. The car takes on a precise trajectory, autonomy and momentum, the flexibility of the components is lost, and the degree of freedom of the human agents is reduced. Recent decades have seen the stabilization of motorized mobility. Furthermore, lifestyles, the social environment, and the organization of the territory adapt to the needs of the automobile. In this article, we will clarify the evolution of motorized mobility in Gipuzkoa and, adopting a socio-technical perspective, we will explain that evolution and make suggestions for a sustainable transport.

Key words: car - technology - socio-technical perspective - innovation - sustainability. 


\section{SARRERA ${ }^{1}$}

Azken hamarkadetan mugikortasun motorizatuak eragin nabaria izan du gure bizitzeko estiloetan, lurraldearen antolaketan edota ondasunen eta zerbitzuen ekoizpenean, komertzializazioan eta banaketan. Lurraldeak eta herritarrok gaur egunean bizitzeko edota lan egiteko ditugun erritmoak, gure aisialdirako ohiturak eta orobat norbanakoa eta bere autonomia ulertzeko moduak ere ezinbestean daude kotxeari lotuta. Eraldaketa eta mutazio horiek guztiak, modernizazioaren osagaiak diren heinean, gizarte-zientziek eta soziologiak luze eta sakon landu dituzte (Featherstone et al., 2005).

Oraintsu, garraioaren eta kotxearen soziologiak oso bestelako dimentsioak aintzat hartzeko jakin-mina piztu du. Horietako bat da garraio jasangarriaren erronkari dagokiona (Banister, 2008). Izan ere, kotxeak altzairuz eginak daude, erregai fosilez propultsatuak dira eta jabetza pribatukoak dira. Gauzak horrela, auzi ekologikoek soziologian garrantzia analitikoa hartu ahala, automobilaren gogoetan ere dimentsio berriak erdigunean kokatzen hasi dira.

Guztiarekin ere, garraioaren ingurumen arazoei buruzko kezkak baditu aurrekariak. Zentzu honetan, 1973ko petrolioaren krisiarekin gaiari buruzko kritika esanguratsuak luzatu dira. Besteak beste, arreta ipiniko dute motorizazio masiboak identitateetan, bizitzeko estiloetan, auzoen eta hirien planifikazioan, paisaian edota komunitatean dituen efektuetan. Neurri batean, aurrekari garrantzitsuak dira, beraz, Andre Gorz (1975), Ivan Illich (1974) edota Henri Lefebvre (2008); gure artean Mario Gaviriak ere egin ditu ekarpenak. $^{2}$

Azken urteotan ostera ere mugikortasunaren inguruko eztabaidak indarra hartzen ari dira. Izan ere, garraioaren eta bereziki automobil pribatuaren inguruko kezka hazten ari da. Honen harira, idazlanaren gaia da automobil pribatua eta ingurumen inpaktua. Bi arrazoi osagarrik justifikatzen dute idazlanaren gaia. Alde batetik, garraioak eta automobil pribatuak ardura erabakigarria dute naturaren gaitasunen ahultze progresiboa egiaztatzen duten adierazle eta magnitudeetan (arazo energetikoak, aldaketa klimatikoa, zerbitzu ekosistemikoen degradazioa, aztarna ekologikoa). Bestetik, ordea, zailtasunak daude mugikortasun motorizatuaren eta automobilaren traiektoria aldatzeko. Idazlanak eraikiko du marko analitiko bat balioko diguna ulertzeko automobilak krisi ekologikoan duen ardura eta automobilaren traiektoria aldatzeko dagoen zailtasuna, hurrenez hurren. Lan-hipotesia da automobilaren kontzeptualizazio teknikoak mugatu egiten duela

\footnotetext{
${ }^{1}$ Idazlana Gipuzkoako Foru Aldundiko (GFA) Ingurumeneko eta Lurralde Antolaketarako Departamenduak finantzaturiko lankidetza hitzarmenaren baitan (2015-2016) egina dago. Idazlana osatzeko Eusko Jaurlaritzako Hezkuntza sailaren 2013-2018 Euskal unibertsitate sistemako ikertaldeen jarduerak bultzatzeko diru-laguntza ere baliatu da (IT644-13).

2 Egia esatera, erabaki teknologiko eta sozialen bigarren eta hirugarren ordenako efektuei buruzko kezkak 1970. hamarkadan oihartzun zabala izan zuen. Honen harira, Daniel Bellek (1973), «the tensions between the economizing and sociologizing modes» iragartzen duenean, automobilaren kasua baliatzen du aldiroko adibideetan.
} 
dimentsioen ugaritasuna detektatzea eta sistemaren aldaketarako neurriak egoki planteatzea.

Gaia konplexua da eta idazlanak ekarpena bi planotan egin nahi du. Alde batetik, plano metodologikoan, automobila eta honen ingurumen inpaktua ulertze aldera, ziklo globalekoa deritzogun hurbilketa iradokitzen dugu. Izan ere, automobilaren ingurumen inpaktuei buruzko analisietan ohikoa da trakzioaren kontsumoari eta emisioari soilik arreta ipintzea. Hori, ordea, ertzetako bat besterik ez da. Analisi osoa egingo badugu, automobilaren eraikuntza, azpiegituren eraikuntza, garraio-sistemaren mantenua eta hondakinen eliminazioa edota gestioa ere integratu beharko ditugu automobilaren ingurumen inpaktua ulertzeko. Automobilaren metabolismoak eskatzen du baliabide naturalen eta energiaren fluxua modu integralean jasotzea. Premisa metodologikoa da, beraz, automobilaren ingurumen inpaktuan dimentsio eta adierazle ugari daudela.

Idazlanaren bigarren ekarpena marko teorikoari eta kontzeptualari lotuta dago. Ikuspegi kognitiboak eta instrumentalak bi ezaugarri dituzte: bata da automobila arterfaktu tekniko modura ulertzen duela; bigarrena da artefaktua eta gizartea bi eremu independente modura zedarritzen dituela. Ikuspegi bi horiek ingeniaritzako premisetan funtsatzen dira, aterabidea automobilaren hobekuntza eta efizientzia teknikoan ezartzen dute, eta modu linealean irudikatzen ditu efizientzia teknikoa, gizartearen aldaketa eta jasangarritasuna. Horretan funtsatu izan dira orain artean mugikortasunari buruzko politika publikoak eta plan estrategikoak ere, hein handi batean. Ikuspegi horren aurrean, idazlanak ikuspegi sozio-teknikoa proposatuko du. Ikuspegi sozio-teknikoak ez ditu gutxiesten garraioaren eta automobilaren auzi teknikoak edota berrikuntza teknologikoaren garrantzia. Baina automobila dimentsio bakarreko artefaktua (erredukzionismoa) bezala ulertu ordez, proposatzen du dimentsio ugariko sistema heterogeneo eta kontingente modura ulertzea. Honen arabera, automobilaren traiektoria ulertzeko beste hainbat osagai ere aintzat hartu behar dira, besteak beste: organizazioak (autogintzaren eremuko manufaktura-industriak, hornitegiak, gobernuak, finantza-entitateak, aseguru-etxeak), osagai zientifikoak (ikerketa-programak, heziketa zentroak), legeak eta erregulazioak, praktika ekonomikoak, osagai kulturalak (balioak, portaerak, aspirazioak) edota baliabide naturalak, besteren artean.

Osagai heterogeneo horiek osatzen dute automobilaren sistema. Zehatzago esanda, automobila sistema sozio-teknikoa da. ${ }^{3}$ Izan ere, artefaktua - automobila- osagai teknikoek ez ezik, giza elementuek ere (ingeniariak, langileak, enpresak, legelariak, kontsumitzaileak) osatzen dute. Gauzak horrela, automobilaren sistema egonkortu izana eta haren traiektoria aldatzeko zailtasunak ulertuko baditugu, ezinbestekoa

\footnotetext{
${ }^{3}$ Ikuspegia osatzeko, Zientzia eta Teknologiaren Gizarte Ikerketak delakotik elikatu naiz. Ikuspegi sozio-teknikoaren proposamena Hughesek (2004) garatu du; ikus orobat Smith eta Marx 1994. Eztabaidaren atalean helduko zaio ikuspegi sozio-teknikoari eta hor luzatuko dugu marko teoriko eta kontzeptuala ere.
} 
izango da osagai heterogeneoak eta horien arteko erlazioak aintzat hartuko dituen marko teoriko eta kontzeptuala eraikitzea. Beste hitzetan esateko, ikuspegi sozio-teknikoak balio digu ulertzeko zergatik den zaila automobilaren traiektoria -kontingentea- aldatzea, guztiok dakigun arren ingurumen inpaktuan aparteko erantzukizuna duela.

Laburbilduz, idazlanak hiru eginkizun zehatz ditu: automobilaren eboluzioaren berri ematea; ingurumen inpaktua azpimarratzea; joerak eta dinamikak aldatzeko dauden zailtasunak identifikatu eta esplikatzea. Hiru bloke nagusi bereiziko dira. Bigarren atalak arreta automobilaren ingurumen inpaktua ulertzeko metodologiari ipiniko dio eta ziklo globalaren metodologia proposatuko da. Hirugarren, laugarren eta bosgarren ataletan emaitza nagusien berri emango da. Hiru atal horietan automobilaren ingurumen inpaktuaren azalpen estatistiko eta deskriptiboa egingo da. Zehazki, arreta berezia ipiniko diogu Gipuzkoako lurraldean eta Euskadiko Autonomia Erkidegoan (EAE) emaniko mugikortasun motorizatuaren bilakaerari. Seigarren atalean, automobilaren traiektoria nola egonkortu den ulertuko dugu eta horretarako automobilaren eztabaida teoriko eta kontzeptuala osatuko da. Eztabaidak bereizi egingo ditu garraioa eta automobila ulertzeko ikuspegi kognitiboa, instrumentala eta sozio-teknikoa. Azken urteotan planifikazio ugari egin dira, baina baliatutako ikuspegiak partzialak dira eta efektu ez-desiragarriak, aurreikusi gabekoak eta zitalak eragin dituzte. Horren aurrean, ikuspegi sozio-teknikoa proposatu eta garatuko dut. Ikuspegiak balio diezaguke azken urteotako planen mugak aletzeko eta auziaren dimentsioen ugaritasunaz ohartzeko. Garraio jasangarria ulertu eta diseinatzeko lehen urratsa izan daiteke.

\section{METODOLOGIA}

Estevanek (1993, 2004) proposatu eta garatu du garraio sektorearen ziklo produktibo osoa kalkulatzeko ikuspegi integratuko metodologia. Automobilaren ingurumen inpaktua kalkulatzeko metodologia berezia eta ezohikoa da. Eredu nagusiek oro har automobilaren trakzioari ipintzen diote arreta eta analisiek trakzioaren kontsumo eta emisio energetikoa neurtzen dituzte. Horren aurrean, ziklo globaleko metodologiak aukera emango digu baliabide naturalean eta energiaren metabolismoa ezagutzeko. Izan ere, Estevanen (1993, 2004) proposamenean, garraioaren ziklo globalak bost eremu lituzke:

1. ibilgailuaren eraikuntza (eta bere ingurumen inpaktua);

2. azpiegituren eraikuntza (eta bere ingurumen inpaktua);

3. zirkulazioa (eta bere ingurumen inpaktua);

4. garraio-sistemaren mantenua (eta bere ingurumen inpaktua); eta,

5. hondakinen eliminazioa edo gestioa (eta bere ingurumen inpaktua). 
Bost eremu hauekin ingurumen inpaktuaren neurketak automobilaren kontsumo eta emisio globala integratzen ditu. Izan ere, aintzat hartzen dira, bost eremu horiekin, zikloaren hiru fase nagusiak: garraioaren funtzionamendurako inputak eta beren ingurumen inpaktuak; garraioaren funtzionamenduaren outputak eta bere ingurumen inpaktuak; eta espazio eta ingurumen inpaktuak. Hiru fase nagusi hauetan integratzen ditugu bost eremu nagusiak, 1. Taulan ikus daitekeenez. Edozein kasutan, ziklo globalaren metodologiak garraio-sistemaren ingurumen inpaktuak oso bestela aztertzea proposatzen du.

Bidenabar, Euskadiko Autonomia Erkidegoan autogintzak duen garrantzia ikusita, aise ulertzen dugu ziklo globalaren egokitasuna: EAEko lantegi pribatu handiena autogintza sektorekoa da; gure industria oso sendoa da autogintzako osagaien hornitzaile modura; makina-tresneriari loturiko industria neurri berezian autogintzarako ari da lanean; autogintzan gurpilgileak eta beiragileak ere badira. Halaber, automobilaren ingurumen inpaktuak, neurri berean, aintzat hartu beharko lituzke, esaterako, erregai solidoen ekoizpena eta hauen garraioa, eraldaketa (errefinategiak), lurraldeko garraioa, edota gasolindegiak. Beste dimentsio inportantea dira, era berean, automobilak munduko sare komertzialean integratze aldera, autobidez, trenez edota portuetara eta gero itsasontziz saretzen den azpiegitura osoa. Azpiegituren eraikuntza eta mantenua ere gogoan izan behar da; zementuaren industria da adibide bat.

Honek guztiak lau ideia agerian uzten ditu: alde batetik, automobilaren sistema heterogeneoa, askotarikoa eta konplexua da; bestetik, idazlanak soilik ingurumen inpaktuari ipiniko dio arreta, baina gaiaren tamainak erakusten du oso bestelako faktore ekonomikoak edota sozialak ere aintzat hartu beharrak daudela, automobilaren garrantzia eta traiektoria aldatzeko zailtasuna ulertuko baditugu, eztabaidaren atalean sakonduko dugun modura; hirugarrenik, automobilaren ingurumen inpaktua ulertzeko, esan bezala, trakzioaren kontsumoa eta emisioa ez ezik, beste hainbat ertz eta fase analisira integratu behar dira; laugarrenik, automobilaren alorreko energiaren eta materiaren fluxuaren metabolismoak erakusten digu tokiko gertakariak ulertzeko planetako dinamika ekologikoak integratu behar direla (Healy et al 2013). Analisi osoak hori guztia aintzat hartzea eskatzen du, hemen egin ezin duguna. Lau ideia horiek, besterik ezean, balio dezatela gaiaren konplexutasuna eta dimentsioen aniztasuna gogoan izateko.

Idazlanaren atal deskriptibo eta estatistikoak, beraz, hainbat muga ditu. Alde batetik, dimentsio batzuk soilik nabarmenduko dira, ariketa estatistiko arruntak ez baitu guztia eskura jartzen. Bestetik, idazlanaren luzera dela eta, adierazle batzuei (1. Taulan zehazturikoei) soilik ipini zaie arreta. Hala eta guztiz ere, emaitzek aski garbi utziko dute arazoaren tamaina. 
1. Taula. Automobilaren inpaktua: ziklo globaleko metodologia

\begin{tabular}{|c|c|c|c|}
\hline & $\begin{array}{l}\text { Ziklo } \\
\text { globalaren } \\
\text { faseak }\end{array}$ & Dimentsioak & Adierazleak \\
\hline \multirow{16}{*}{ Automobila } & \multirow{7}{*}{$\begin{array}{l}\text { Eraikuntzaren } \\
\text { fasea }\end{array}$} & $\begin{array}{l}\text { Garraio motak eta hauek iza- } \\
\text { niko bilakaera }\end{array}$ & $\begin{array}{l}\text { Ibilgailuen tamaina } \\
\text { Automobil parkea } \\
\text { Automobil parkearen berritze } \\
\text { intentsitatea } \\
\text { Motorizazio indizea } \\
\text { Ibilgailuen efizientzia }\end{array}$ \\
\hline & & Ibilgailuen trakzioa & $\begin{array}{l}\text { Kontsumitutako erregai mota } \\
\text { Desplazamenduak } \\
\text { Ibilgailu-parkearen eta bide-az- } \\
\text { piegituren ratioa }\end{array}$ \\
\hline & & $\begin{array}{l}\text { Ibilgailuen eraikuntza eta man- } \\
\text { tenua }\end{array}$ & \\
\hline & & $\begin{array}{l}\text { Azpiegituren eraikuntza eta } \\
\text { mantenua }\end{array}$ & \\
\hline & & Autopista-sareak & \\
\hline & & $\begin{array}{l}\text { Energia kontsumoa (koste ener- } \\
\text { getikoa) }\end{array}$ & \\
\hline & & $\begin{array}{l}\text { Garraioaren inguruko aktibitate } \\
\text { osagarriak eta beren ingurumen } \\
\text { inpaktua }\end{array}$ & \\
\hline & \multirow{4}{*}{$\begin{array}{l}\text { Isurketaren } \\
\text { fasea }\end{array}$} & Ibilgailuen trakzioa & \\
\hline & & $\begin{array}{l}\text { Ibilgailuen zein azpiegituren } \\
\text { eraikuntza }\end{array}$ & $\begin{array}{l}\text { Garraioaren kanpo kostua } \\
\text { Gasen isurketa }\end{array}$ \\
\hline & & $\begin{array}{l}\text { Ibilgailuen zein azpiegituren } \\
\text { mantenua }\end{array}$ & \\
\hline & & $\begin{array}{l}\text { Hondakinen eliminazioa eta } \\
\text { gestioa }\end{array}$ & \\
\hline & \multirow{5}{*}{$\begin{array}{l}\text { Espazioa, } \\
\text { ingurumena }\end{array}$} & Azpiegituren eraikuntza & $\begin{array}{l}\text { Errepide proiektuen kostua } \\
\text { Diseinuaren parametroak } \\
\text { Obren kostea }\end{array}$ \\
\hline & & Abiadura & \\
\hline & & Lurzoruaren okupazioa & $\begin{array}{l}\text { Lurraren kontsumoa } \\
\text { Espazioa eta ingurumena } \\
\text { Segurtasuna } \\
\text { Zarata } \\
\text { Inguruen degradazioa } \\
\text { Zoruaren asfaltizazioa } \\
\text { Zoruaren gaitasun produktiboa }\end{array}$ \\
\hline & & Lurraldearen antolaketa & \\
\hline & & Paisaia & \\
\hline
\end{tabular}




\section{ERAIKUNTZAREN FASEA}

Ziklo globalaren ikuspegiak, hasteko eta behin, garraioaren funtzionamendurako inputak eta bere ingurumen inpaktuak bere osotasunean aztertzea eskatzen du. Metodologiaren atalean aipatu dira dimentsio eta adierazleak.

Kontsumo energetiko agregatuei arreta ipintzen badiegu, portzentajezko distribuzioak ondorio adierazgarria aurreratzen digu: faktura energetiko globalean hazi egin da ibilgailuen eraikuntzarako fasearen eragina. Alegia, ibilgailuen erregai kontsumo espezifikoa jaitsi egin da (ibilgailuak efizienteagoak dira), baina aldi berean hazi egin dira ibilgailuen bataz besteko tamaina (matrikulatutako ibilgailuen bataz besteko zilindrada, ibilgailuen pisua, ibilgailuen potentzia), bai eta ere automobil parkearen berritze intentsitatea eta mugikortasunaren motorizazioa.

Ibilgailu-parkeak datu esanguratsua aurreratzen digu: karrozeria mota guztiek (turismoa, motozikleta, kamioia eta furgoneta, autobusa, traktore industriala, beste ibilgailuak) gora egin dute, etenik gabe, eta EAEko lurralde guztietan. Gipuzkoako lurraldean eta turismoei dagokionez, 2013ko datuekin, 303.919 turismo daude, ibilgailu-parkearen \%68,9. Ikuspegi longitudinala hona aldatzen badugu, 1992an 210.309 turismo bazeuden, 2012an goia joko du eta 306.729 turismotara iritsiko da (2. Taula). Jakina, serie historikoak bagenitu lehenagokoak, argituko genuke hamarkada gutxiren buruan aldatu dela automobilaren kultura eta bere sistema osoa.

2. Taula. Ibilgailu-parkea. Turismoak

\begin{tabular}{|l|c|c|c|c|c|c|}
\hline & 1992 & 1996 & 2000 & 2004 & 2008 & 2012 \\
\hline Gipuzkoa & 210.309 & 229.360 & 263.933 & 282.987 & 301.700 & 306.729 \\
\hline EAE & 651.265 & 716.015 & 820.618 & 874.085 & 939.235 & 955.930 \\
\hline
\end{tabular}

Iturria: EUSTAT. Unitatea: ibilgailu kopurua.

Datu horien esanahia ulertzen laguntzen digu motorizazio indizeak (3. Taula). Beti ere turismoak soilik aintzat hartuta, motorizazio indizeak erakusten digu 1.000 biztanleko zenbat turismo dagoen. Hala, emaitzek baieztatzen digute hazkundea etengabea dela: 1992. urtean 317 turismo bazeuden 1.000 biztanleko, hamar urteren buruan, 2013an, 1.000 biztanleko 430 turismo daude.

Denboran izaniko bilakaera ez ezik, alderaketa geografikoa ere egin genezake. Europarekin egingo dugu alderaketa. Oro har, motorizazio indizea nabarmen handiagoa da Europako herrialdeetan. 2012ko datuekin, 1.000 biztanleko turismo kopuru handienak dituzte Luxenburgok (663) eta Italiak (621); 500-600 bitartean aurkitzen ditugu Malta, Lituania, Finlandia, Txipre, Austria, Alemania eta Eslobenia; 400-500 bitartean daude Belgika, Es- 
painia, Herbehereak, Polonia, Erresuma Batua, Suedia, Grezia eta Portugal (EAEko bataz bestekoa ere 436 turismo 1000 biztanleko da). Datuak nondik begiratu, ordea, esango dugu motorizazio indizearen rankingean atzetik dauden herrialdeak direla ratioan hazkunde deigarriena izan dutenak ere (Estoniak \%5,3, Bulgariak \%4,6, Eslobakiak \%4, Errumaniak \%3,7). 2011ko datu estatikoarekin, EAEn, lurraldeka, Araban 462 turismo dago 1.000 biztanleko, eta Bizkaian eta Gipuzkoan 432 eta 431, hurrenez hurren.

3. Taula. Motorizazio indizea

\begin{tabular}{|l|c|c|c|c|c|c|c|c|c|c|}
\hline & $\mathbf{1 9 9 4}$ & $\mathbf{1 9 9 6}$ & $\mathbf{1 9 9 8}$ & $\mathbf{2 0 0 0}$ & $\mathbf{2 0 0 2}$ & $\mathbf{2 0 0 4}$ & $\mathbf{2 0 0 6}$ & $\mathbf{2 0 0 8}$ & $\mathbf{2 0 1 0}$ & $\mathbf{2 0 1 2}$ \\
\hline Gipuzkoa & 317,0 & 339,2 & 365,2 & 388,5 & 405,4 & 412,2 & 416,1 & 430,4 & 428,8 & 430,7 \\
\hline EAE & 316,5 & 341,3 & 366,6 & 391,0 & 408,5 & 413,2 & 418,7 & 435,4 & 436,0 & 435,9 \\
\hline
\end{tabular}

Iturria: EUSTAT. Unitatea: Turismoak / 1000 biztanle.

2009ko datuekin, EAEn, etxebizitza bakoitzeko bataz beste 1,4 kotxe daude, familien mugikortasunean garraio pribatuaren pisua agerian uzten duena. Ibilgailu-parkeak eta motorizazio indizeak ertz bat erakusten digute. Bigarren ertz bati helduko diot jarraian, zehazki, ibilgailuen efizientziari.

Efizientziaren gaiak testuingurua kontuan izan behar du. Planifikazio energetikoaren testuinguruan, garraioaren sektorean hainbat neurri hartu dira azken urteetan. Laguntzen artean (subentzioak eta zerga kenkariak) ondoko hiruak aipatu daitezke: zerga neurriak automobilen $\mathrm{CO}_{2}$ isurketaren arabera; laguntzak ibilgailu elektrikoei; bioerregaiak erabiltzeko apustua. Laguntza horiei lotuta, Espainiako gobernuak ibilgailu efizienteak sustatzeko programak martxan jarri ditu, 10 urteko antzinatasuna duten turismoak kontsumo txikiagokoengatik ordezkatzeko helburuarekin. Bestetik, azken urteotako ibilgailuen eredu berriak efizienteagoak dira, erregai gutxiago kontsumitzen dute ibilitako distantzia unitate bakoitzeko. Ertz honek merezi du arreta, garraio sektoreak eta nagusiki errepideko garraioak dituen koste energetikoagatik eta $\mathrm{CO}_{2}$ isurketagatik.

Lehen hurbilketa batean, aipaturiko neurriek ondorioak izan dituztela ikus daiteke. Emititutako $\mathrm{CO}_{2}$ tartearen araberako matrikulazioak (ikus 4. Taula) erakusten digu azken urteotan urrats nabaria eman dela.

Urratsa eman da, baina emititutako $\mathrm{CO}_{2}$ tartearen araberako matrikulazioei buruzko datuak bere horretan baliatzeak interpretazio partziala egitea dakar. Argazki egokiagoa erdietsiko dugu, erregai motaren araberako matrikulazioen adierazleak gure analisira integratuta. Izan ere, erregai motaren araberako matrikulazioen adierazleak balioko digu kontsumo energetikoaren beste dimentsio bati heltzeko. Adierazlea bi azpi-adierazletan bereiziko dut. 
4. Taula. Emititutako $\mathrm{CO}_{2}$ tartearen araberako matrikulazioak Gipuzkoan

\begin{tabular}{|c|r|r|r|r|r|r|r|}
\hline & \multicolumn{1}{|c|}{$\mathbf{2 0 0 7}$} & \multicolumn{1}{c|}{$\mathbf{2 0 0 8}$} & \multicolumn{1}{c|}{$\mathbf{2 0 0 9}$} & \multicolumn{1}{c|}{$\mathbf{2 0 1 0}$} & \multicolumn{1}{c|}{$\mathbf{2 0 1 1}$} & \multicolumn{1}{c|}{2012} & \multicolumn{1}{c|}{$\mathbf{2 0 1 3}$} \\
\hline$<=120$ & 1.223 & 1.691 & 3.207 & 2.886 & 2.480 & 2.737 & 4.027 \\
\hline$>120<160$ & 8.973 & 6.797 & 6.761 & 6.090 & 4.989 & 4.155 & 3.711 \\
\hline$>=160<200$ & 5.407 & 3.238 & 2.107 & 1.601 & 1.304 & 873 & 444 \\
\hline$>=200$ & 1.756 & 760 & 514 & 393 & 263 & 153 & 90 \\
\hline Gainerakoa & 10 & 41 & 23 & 52 & 16 & 5 & 10 \\
\hline Guztira & 17.369 & 12.527 & 12.612 & 11.022 & 9.052 & 7.923 & 8.282 \\
\hline
\end{tabular}

Iturria: EUSTAT. Unitatea: Matrikulazio kopurua. Oin-oharra: Turismo eta lurrorotako automobilen matrikulazioak hartzen dira kontua.

Lehen azpi-adierazle batek garraioaren energia kontsumoa azpisektoreka eta energia motaren arabera bereizten digu (ikus 5. Taula). Errepideetako azpi-sektorean (beraz, turismoak bakarrik ez) petrolio eta deribatuek \%93 suposatzen dute, urteen arabera bariazio hutsalekin; energia berriztagarrietan azken urteetan aldaketa antzematen da: 2003an $\% 0,0$ bazen, 2007an \%1,2, 2010ean \%5,8 eta eta 2013an \%6 da.

5. Taula. Garraioaren energia kontsumoa errepideko azpisektorean eta energia motaren arabera

\begin{tabular}{|c|l|r|r|r|r|r|r|r|c|}
\hline Unitateak & \multicolumn{1}{|c|}{ Energia mota } & $\mathbf{2 0 0 2}$ & $\mathbf{2 0 0 4}$ & $\mathbf{2 0 0 8}$ & $\mathbf{2 0 0 9}$ & $\mathbf{2 0 1 0}$ & $\mathbf{2 0 1 1}$ & $\mathbf{2 0 1 2}$ & $\mathbf{2 0 1 3}$ \\
\hline$\%$ & Petrolio eta deribatuak & 93,5 & 94,6 & 92,2 & 91,4 & 88,6 & 88,2 & 94,0 & 93,9 \\
\hline$\%$ & Energia berriztagarriak & 0,0 & 0,2 & 2,3 & 3,4 & 5,8 & 5,8 & 6,0 & 6,1 \\
\hline
\end{tabular}

Iturria: EEE Energiaren Euskal Erakundea. Unitatea: ktpb.

Hau osatzeko, bigarren azpi-adierazlea da garraioaren energia kontsumoa lurraldeka. 6. Taulan ikus genezake Gipuzkoako garraio sektoreko energia kontsumoa, kontsumitutako energia motaren arabera sailkatuta.

6. Taula. Gipuzkoako garraio sektoreko energia kontsumoa, kontsumitutako energia motaren arabera sailkatuta

\begin{tabular}{|l|r|r|r|r|r|r|r|r|r|r|r|r|}
\hline \multicolumn{1}{|c|}{ Energia mota } & $\mathbf{2 0 0 2}$ & $\mathbf{2 0 0 3}$ & $\mathbf{2 0 0 4}$ & $\mathbf{2 0 0 5}$ & $\mathbf{2 0 0 6}$ & $\mathbf{2 0 0 7}$ & $\mathbf{2 0 0 8}$ & $\mathbf{2 0 0 9}$ & $\mathbf{2 0 1 0}$ & $\mathbf{2 0 1 1}$ & $\mathbf{2 0 1 2}$ & $\mathbf{2 0 1 3}$ \\
\hline Energia elektrikoa & 1,8 & 1,0 & 0,8 & 0,7 & 0,9 & 0,7 & 0,8 & 0,7 & 0,7 & 0,6 & 0,6 & 0,6 \\
\hline A eta B gasoilak & 79,0 & 80,0 & 81,0 & 83,0 & 84,0 & 85,0 & 84,0 & 82,0 & 80,6 & 80,9 & 82,5 & 83,1 \\
\hline Gasolinak & 20,0 & 19,0 & 18,0 & 16,0 & 15,0 & 13,0 & 13,0 & 13,0 & 12,3 & 11,9 & 10,8 & 10,1 \\
\hline Bioerregaiak & & - & 0,0 & 0,0 & 0,0 & 1,3 & 2,4 & 3,6 & 6,1 & 6,1 & 6,0 & 6,0 \\
\hline
\end{tabular}

Iturria: EEE Energiaren Euskal Erakundea. Unitatea: ktpb. 
Azken bi azpi-adierazleak (5. eta 6. taulak) aintzat hartuta, beraz, 4. taulak iradokitzen duena lausotu egiten da eta, hedaduraz, automobilaren planifikazio energetikoaren irismena ere bai. Beste hitzetan esateko, matrikulazio berrietan emititutako $\mathrm{CO}_{2}$ tarteak irakurketa positiborako abagunea iradoki arren, kontsumitutako erregai motek datuen hobekuntza mugatu egiten dute. Petrolioak tentsio ugari irekitzen ditu: gaitasun energetiko apartekoa du, baina baliabide mugatua, ez-berriztagarria eta kutsakorra ere bada.

Guztiarekin, garraio-sistemaren kontsumo energetikoak, gure metodologiaren ikuspegitik, hobekuntza metodologiko estatistikoak eskatzen ditu. Izan ere, kontuan soilik hartzen da garraioaren trakzioari loturiko kontsumo energetikoa, garraioaren funtzionamendurako beste dimentsioak (garraioaren eraikuntza eta mantenua, azpiegituren eraikuntza eta mantenua) alde batera utzita. Gogora dezagun, atalaren helburua da automobil pribatuaren ingurumen inpaktuaren lekuko batzuk hona aldatzea, baina ikuspegi integratuak auzia gehiago kontsideratzen ditu. Izan ere, ziklo globalaren metodologiak iradokitzen du automobilaren eraikuntzaren eta garraio-sistemaren mantenuaren ingurumen inpaktuak ere aintzat hartu behar direla, ez soilik trakzioaren kontsumo eta emisioari dagozkionak. Gaia oso konplexua da, beraz.

Nolanahi den, garraioaren trakzioaren kontsumo energetikora mugatuta ere, datuak azpimarratzekoak dira. Kontsumo energetikoari arreta ipintzen badiogu, hasteko eta behin, Energiaren Euskal Erakundearen datu energetikoek erakusten digutenez, azken hamar urteetan (2003-2013) energiaren kontsumo finalean garraioaren sektorea da eboluzio desberdina izan duena: 2003 urteko bolumenarekin alderatuta, \% 5,3ko jaitsiera metatua eman da (kontsumo finalean 2013an EAEn 5048 ktep kontsumitu dira), baina garraioaren sektorean -bizitokiaren, zerbitzuen, nekazaritza eta arrantzaren, industriaren kasuekin alderatuta-, joera bestelakoa da, eta \%11,4 igo da. Zehazki, 2013an garraio sektorearen energiaren kontsumo finala 1846 ktep da. Orotara, kontsumo final energetikoa sektoreka aletuz gero, hauek dira emaitzak: garraioa \%36,6 izatera heldu da, soilik aktibitate industrialekoak gainditua $(\% 41,6)$, eta besteetan lehen sektoreak $\% 1,5$, zerbitzuek $\% 8,8$, bizitokiak \%11,5. (Metodologia integrala egoki beteta, noski, garraio-sistemaren kontsumo final energetikoa oso bestelakoa zatekeen.)

Honi guztiari erantsi behar diogu garraio sektorean errepidekoak \% 95,3 suposatzen duela, ikusi bezala, petrolio-produktuekiko erabateko menpekotasunarekin, gainera. Gipuzkoari arreta zehatzagoa ipinita, berriz, 2003-2013 urteen bitartean garraio-sektorearen kontsumo energetikoa \%6,8 igo da eta EAEko eremuan Gipuzkoak sektorearen \%38,1 gastatzen du (Bizkaian jaitsi egin da \%5,1 eta sektoreko kontsumoaren \%36,5 kontzentratzen du; Araban \%6,32 igo da eta guztiaren \%25,3 ordezkatzen du). Gauzak horrela, EAEn, garraioaren faktura energetikoari dagokionean, 2863 milioi euroko zenbatekoa kontabilizatu zen eta faktore energetikoaren kostearen \%47 pilatzen du. Zentzu honetan, garraio sektorearen faktura energetikoaren eboluzioari arreta ipinita, EAEn hamar urteren buruan garraio sektorearen faktura energetikoa milioi eurotan bikoiztu egin da. 
Baina, esan bezala, gaia aise konplikatuagoa da. Datu hauek osatu egin beharko lirateke, garraio-sektorearen eta gure kasuan, turismoen kontsumo energetikoaren ziklo osoa aintzat hartuz gero. Honek iradokitzen du garraio sektoreak, bereziki errepidekoak, eta modu nabarmenean turismoen kasuak, ardura nabaria duela kontsumo energetikoan. Egia esatera, goian aipatu diren hainbat datu, bereziki kontsumo energetiko finalari dagozkionak, errebisatzeko premia legoke, baina momentuz eskura ditugunek ere joera nabaria iradokitzen dute.

Orain artean, bi ertzi ipini diet arreta: lehendabizi, ibilgailu-parkea eta motorizazio indizeak aztertu ditugu; eta, gero, ibilgailuen efizientzia eta kontsumo energetikoa. Azterketaren hirugarren ertza mugikortasunaren motorizazioa eta erregai kontsumoa da.

Datu batzuek balio digute lehen irakurketa — partziala - egiteko. Lanegunei buruzko azterketak dira eskuartean ditugunak eta hainbat joera antzemateko balio digute. Ikusi dugu motorizazioaren hazkunde nabaria dagoela. Gipuzkoan 2011ko urtean \%37,1 da automobilaren erabilera tasa. Hiriarteko desplazamenduetan (guztiaren \%66,5) automobilarekin egiten da desplazamenduen \%70; EAEko lurraldeen arteko (guztiaren \%23,8) eta EAEtik kanporako (guztiaren \%9,1) desplazamenduetan automobilaren erabilerari buruzko indizeak nabarmendu egiten dira: Araba eta Gipuzkoa arteko mugimenduen \%92 eta Bizkaia eta Gipuzkoaren arteko mugimenduen \%82,4 automobilarekin egiten dira. Hirietarako sarbideei buruzko 2011ko datuek ere erakusten dute auto pribatuaren garrantzia; Donostiara egunero 983030 desplazamendu. (Pasarte hauek, garraioaren erabilerari buruzkoak dira, baina ingurumen efektuei buruzko argibideak ematen dizkigute, geroago ikusiko dugunez. Bestalde, aintzat hartu behar da errepideko garraio pribatuaz soilik ari garela.)

Era berean, arreta garraio modu indibidualei jarrita (kotxea, taxia, motoa), kotxeak desplazamenduen \%97,1 suposatzen du. EAE osoa hartuta, bidaiaren \%82,1 gidariak dira eta beste \%17,9 laguntzaileak; EAE barruko desplazamenduetan, berriz, \%84,1 eta \%15,9, hurrenez hurren. Bestetik, barne desplazamenduak 2011ko urtean orotara laneguneko bataz beste 2179286 egin dira (orotara beste garraio moduak hartuta, 3.183.268 desplazamendu), eta EAEko desplazamenduen \%92,3 herrialdearen barruan egiten da, eta \%7,7 hiru lurraldeen artean. Honen ildotik, eguneroko mugikortasunaren motibo nagusia lana izan ohi da (EAE barruko desplazamenduen \%60,4 lanagatik egiten da), desplazamendua oro har turismo pribatuan egiten da eta nagusiki modu indibidualean. Desplazamenduen distribuzioei arreta zehatzagoa ipinita, modu indibidualean egiten diren desplazamendu tipoetatik \%36 da hiribarrukoa eta 34,8 komarka barrukoa. Hiriburuetan modu indibidualeko barne desplazamenduak guztiaren 17,4 dira, eta hiriburuen artean, Donostia da penetrazio kuota handienekoa (\%26).

Halere, eskura ditugun azterketek irakurketa partziala egiten dute; ona litzateke azterketa zabaltzea asteburuetara, edota aztergaietan integratzea ikuspegi longitudinalean oinarrituz, gure bizitza-estiloak (erosketak, aisialdia) nola aldatu diren eta horien interakzioa mugikortasun-ereduekin. Izan ere, ibilbide laburretan mugikortasun ohiturak aldatu dira 
(turismoen erabilera handitu da), kontsumoari lotutako aktibitateak eta mugikortasun motorizatua elkarri lotuta agertzen dira, eta oro har normalizatu egin da bidaiak (ibilbide luzeko joan-etorriak, oporrak) automobilean egiteko joera ere. Analisi horien faltan, irakurketa partziala da.

Iradokizun hauei estuki lotuta, hirugarren ertza osatze aldera, azpimarratzea merezi duen beste ideia bat dago: gaur eguneko kotxearen erabilera modua dela eta, erregai kontsumoa hazi egin da. Izan ere, erregai kontsumoaren errejimen optimotik aldentzen gaituzte automobilaren erabilera ohikoenek: gero eta arruntagoa da traiektu laburretarako kotxea hartzea eta halaber ohiturazkoa bilakatu da traiektu luzeak egitea, eta neurri horretan kontsumitutako erregai kantitatea hazi ez ezik zirkulazio abiadura desegokiak ere ugaritu dira.

Azaldutakoak balio digu lehen ondorio bat («errebote efektua») planteatzeko. Alde batetik, ibilgailuak gero eta efizienteagoak dira. Bestetik, ordea, gure bizitza-ohiturak daude, eta hemen ibilgailuen funtzionamendurako inputek eta bere ingurumen inpaktuek bestelako tendentzia iradokitzen dute: ez soilik ibilgailuen parkea eta motorizazio indizea hasi direlako, baizik eta gidarien ohiturengatik ere bai; erositako kotxeak handiagoak dira eta potentzia handiagokoak, eta mugikortasun motorizatua eta erregaien kontsumoa ere hazi egin dira.

Orobat, hauek dira lehen ondorio nagusiak: turismoen (eta oro har errepideko garraioaren) hazkunde nabaria; petrolioarekiko menpekotasuna saihesteko aldaketa estrukturalen zantzurik gabe; eta guztiaren ondorio modura, garraio sektorearen ingurumen errendimendu urria. [Aurrerago ikusiko dugunez, hori lotuta dago automobilen $\mathrm{CO}_{2}$ isurketa.]

Haatik, ibilgailuaren funtzionamenduak ertz gehiago ditu. Hiru ertz aipatu ditut, baina gehiago ere badira. Besteak beste, turismoaren eraikuntzari lotutako energiaren eta materialen fluxua aintzat hartu behar genuke, baita turismoaren mantenurako behar direnak ere, eta horri erantsi beharko litzaioke azpiegituren eraikuntza eta mantenua. Horiek ere beharrezkoak dira ibilgailuaren funtzionamendurako; ingurumen inpaktua, trakzioak ez ezik, turismoaren eraikuntzak eta mantenuak ere badute. Orain artean aipatu ditut —soilik - turismoaren trakzioari buruzko koste energetikoak. Datu estatistikoak hor geratzen dira, eta horren argitan neurtzen dute garraioak dituen kostu energetikoak. Baina errealitatea hori baino konplexuagoa da, baldin eta garraioaren analisian integratzen baditugu garraioaren funtzionamendurako input guztiak (eta bere ingurumen efektuak). Kasu horretan, garraio sektorearen energia eta materialen fluxua nabarmen hazten da.

Honen harira, baditugu eskura datu batzuk. Alde batetik, ibilgailu-parkearen eta bide-azpiegituren ratioa dugu. 2013ko datuekin, EAEko errepide-sareak 4.175 kilometro ditu. Zehazki, guztiaren \%14,4 da autopistek, autobiek eta galtzada bikoitzekoek osaturikoa. Gipuzkoako errepide-sarearen longitudeari dagokionean (7. Taula), aldaketa nabarienak bide motan eman dira. 
7. Taula. Errepide-sarea Gipuzkoan. Luzera (km)

\begin{tabular}{|l|r|r|r|r|r|r|r|}
\hline & 1992 & \multicolumn{1}{|c|}{1996} & \multicolumn{1}{|c|}{2000} & \multicolumn{1}{|c|}{2005} & \multicolumn{1}{c|}{2007} & \multicolumn{1}{c|}{2009} & 2012 \\
\hline Bidesaridun autopistak & 70,0 & 70,0 & 75,0 & 86,0 & 81,0 & 97,0 & 96,0 \\
\hline $\begin{array}{l}\text { Autopista libreak, autobideak, galt- } \\
\text { zada bikoitzeko bideak }\end{array}$ & 52,0 & 69,0 & 83,0 & 91,0 & 107,0 & 114,0 & 123,0 \\
\hline Galtzada bakarreko errepideak & $1.182,0$ & $1.197,0$ & $1.198,0$ & $1.194,0$ & $1.191,0$ & $1.195,0$ & $1.193,0$ \\
\hline Guztira & $1.304,0$ & $1.336,0$ & $1.356,0$ & $1.371,0$ & $1.379,0$ & $1.406,0$ & $1.412,0$ \\
\hline
\end{tabular}

Iturriak: Sustapen Ministeritza eta INE. Unitatea: $\mathrm{km} ; \mathrm{m} / \mathrm{km}^{2}$.

Dentsitatea (errepide sarearen longitudea eta lurraldearen azalera kontuan hartuta), 2013an, EAEri dagokionean, 577,1 m/ $\mathrm{km}^{2}$ da; konparaziorako, Estatukoa 326,8 m/km² eta 436,3 m/km² Europakoa dira, hurrenez hurren. Urte horretarako (2013. urtea), errepideen modalitateak aletuta, dentsitateak honela banatzen dira: bidesariko autobidezatietan $34,3 \mathrm{~m} / \mathrm{km}^{2}$, autobideetan eta galtzada bikoitzeko errepideetan $48,7 \mathrm{~m} / \mathrm{km}^{2}$, eta galtzada bakarreko errepideetan $494,2 \mathrm{~m} / \mathrm{km}^{2}$. Lehen bi modalitatetako errepideetan (bidesariko autobide-zatietan eta autobideetan eta galtzada bikoitzeko errepideetan) EAEko dentsitatea nabarmen handiagoa da, Europakorekin eta Estatukoarekin alderatuta.

Gipuzkoan, errepide-sarearen dentsitateak bilakaera hau izan du, orotara: $658,5 \mathrm{~m} / \mathrm{km}^{2}$ (1992an), 674,6 m/km² (1996an), 684,7 m/ $/ \mathrm{km}^{2}$ (2000an), 692,3 m/km² (2005ean), 696,3 m/km² (2007an), eta $713 \mathrm{~m} / \mathrm{km}^{2}$ (2012an). Amaitzeko, emaniko datuekin, 8. taulan ikus daiteke ibilgailu-parkearen eta bide-azpiegitura haztatuaren ratioa.

8. Taula. Ibilgailu-parkearen eta bide-azpiegitura haztatuaren ratioa

\begin{tabular}{|l|c|c|c|c|c|c|c|}
\hline & 1992 & 1996 & 1998 & 2002 & 2005 & 2008 & 2013 \\
\hline Gipuzkoa & 191 & 205 & 230 & 248 & 256 & 275 & 273 \\
\hline EAE & 170 & 192 & 205 & 233 & 246 & 266 & 272 \\
\hline
\end{tabular}

Iturria: Eustat. Unitatea: Ibilgailu kopurua bide-sare haztatuko kilometroko (bi-bideko $\mathrm{km} \times 2$, eta bidebakarreko $\mathrm{km} \times 1$ ).

Gogoan izan behar dugu, ibilgailuen trakzioa ez ezik, garraioaren funtzionamendurako inputak eta bere ingurumen inpaktuak ulertze aldera, hainbat direla aintzat hartu beharreko dimentsioak. Hemen saiatu naiz horren berri ematen, baina ziklo osoaren metodologiak irakurketa globalagoa dela diosku. Momentuz aski dira aurkezturiko adierazleak eta emaniko datuak, joerak iradokitzeko behintzat. 


\section{ISURKETAREN FASEA}

Lehenengo zatian garraioaren funtzionamendurako inputei eta horien ingurumen inpaktuei ipini diet arreta. Ziklo globalaren ikuspegiak, bigarrenik, eskatzen du arreta ipintzea garraioaren funtzionamendurako outputei eta bere ingurumen inpaktuei. Kasu honetan ere, ikuspegi integratua baliatuz gero, arreta ipini beharko litzaioke ibilgailuen trakzioak ez ezik, baita ere ibilgailuen zein azpiegituren eraikuntzak eta mantenuak suposatzen dituzten isurketei eta hauen ingurumen inpaktuari. Zehaztapen hau gogoan izanda, muga gaitezen joerak egiaztatzeko aski diren hainbat adierazle aurkeztu eta datuak ematera.

Adierazleetako bat da garraioen kanpo kostua deritzona. Honek hainbat azpi-adierazle erabiltzen ditu, hala nola: aldaketa klimatikoaren kostuak, istripuen kostuak, zarataren kostuak, airezko kutsaduraren kostuak, natura eta paisaiaren kostuak, hiri barneko kostuak, zeharkako bideetatiko kostuak eta auto-pilaketaren kostuak. Alderaketak eginda, garraioaren kanpo kostuen \%97,3 errepideko garraioak eragiten du. Kostuak beti ere mila eurotan (unitatea) kalkulatzen ditu, eta 9. taulan daude jasota, errepidera eta zehazki bidaiaren garraio-tipora mugatuta.

9. Taula. Garraioren kanpo kostuak. EAE. Errepidez. Bidaiariak

\begin{tabular}{|l|r|c|}
\hline & \multicolumn{1}{|c|}{2004} & \multicolumn{1}{c|}{2008} \\
\hline Klima aldaketaren kostuak e.m. & 33.066 & 35.490 \\
\hline Istripuen kostuak & 604.535 & 433.000 \\
\hline Zarataren kostuak & 46.669 & 50.800 \\
\hline Airezko kutsaduraren kostuak & 233.509 & 232.600 \\
\hline Natura eta paisaian kostuak & 30.581 & 31.300 \\
\hline Hiri barneko kostuak & 36.189 & 36.200 \\
\hline Zeharkako bideetatiko kostuak e.m. & 13.436 & 14.410 \\
\hline Auto pilaketariko kostuak & 183.247 & - \\
\hline Guztira & 1.181 .232 & - \\
\hline
\end{tabular}

Iturria: Eustat. Unitatea: milaka eurotan.

Taula behatz-puntekin irakurri behar da, kostuak ez direlako soilik milaka eurotan kalkulatzekoak (badira bestelako kostuak eta gainera eztabaidagarria da kostu horiek monetaritzearen egokitasuna). Edozein kasutan, kanpo kostuei buruzko zerrendak balio digu gogoan izateko inpaktuak dimentsio ugari hartu behar dituela eta, esan bezala, dimentsio horietako bakoitzak askotariko gaiak (osasunekoak, denbora erabilerakoak, ingurumenekoak) dituela.

Adibide batzuk jar daitezke: auto-pilaketen kostuak abiaduran eragiten du, eta beraz, energiaren kontsumoan eta emisioan, baina baita ere gidariaren denboran eta bizitza- 
erritmoan; hiri eremuak dira garraioren zarataren kutsadura gehien pairatzen dutenak eta interferentziak ditu loaldian, ahozko komunikazioan, eguneroko jardunean, horrek bidenabar berarekin dituen kontrako hainbat efektu psikologiko eta fisiologiko guztiekin; naturan eta paisaian efektu kaltegarriak zuzenekoak ez ezik, zeharkakoak, epe luzerakoak eta ertz askotakoak ere badira (eragina dute garraioaren funtzionamenduaren aurreko eta osteko faseek: energia eta erregaien produkzio faseek, fabrikazio eta mantenu faseek, ibilgailuaren desegite faseak, baita azpiegiturei loturikoek ere): biodibertsitatean eta paisaian eragindako kalteek efektu ugari dituzte.

Outputei buruzko atalean, orain artean garraioen kanpo kostuaren adierazleaz aritu naiz. Emisioena da beste adierazle bat. Hemen azalpena bi planotan bereizi ahal dugu. Lehen planoa garraio sektoreko berotegi efektudun gasen emisioari dagokio (10. Taula).

10. Taula. Garraio sektoreko berotegi efektudun gasen emisioa EAEn $\left(\mathrm{CO}_{2}\right.$ ri baliokidea zaion milaka tona)

\begin{tabular}{|c|c|c|c|c|c|c|c|}
\hline 1990 & 1992 & 1996 & 1999 & 2000 & 2004 & 2007 & 2013 \\
\hline 2.717 & 2.950 & 3.100 & 3.500 & 4.600 & 5.232 & 6.080 & 5.364 \\
\hline
\end{tabular}

Iturria: EUSTAT. Unitatea: $\mathrm{CO}_{2}$ ri baliokidea zaion milaka ton.

Plano zehatzagoan, arreta automobilei ipini beharko genieke. Kasu honetan, zuzeneko daturik ez dago. Eskura dauden datuak beti ere dira emititutako $\mathrm{CO}_{2}$ tartearen araberako matrikulazioen eta erregai motaren araberako matrikulazioaren adierazleetatik eratorriak, gorago azaldu dugunez. Halere, orain arteko datuekin, baditugu zantzuak, kutsadura txikiagoko ibilgailuen hobekuntza erlatibizatzeko. Modu zehatzagoan, ondokoa iradoki genezake: mugikortasunaren motorizazioarekin, gaur eguneko kotxearen erabilera dela eta, erregai kontsumoa haztearekin batera, automobilen $\mathrm{CO}_{2}$ isurketa ere handitu egin da. Bestela esanda: automobilen $\mathrm{CO}_{2}$ isurketa erregaien kontsumoari dago lotuta eta kontsumo hori kontsumitutako erregai kantitatearen eta zirkulazio abiaduraren araberakoa denez, kontsumoa errejimen optimoaren gainetik dago. (Errepide sareko tramoetan bataz besteko abiadurek erakusten dute errejimen optimoa deritzogunetik aldenduta daudela.)

Azal dezadan zehatzago. Automobilen $\mathrm{CO}_{2}$ isuria proportzionala zaio erregaien kontsumoari (kontsumoa eta abiadura elkarri lotuta daude). Errejimen optimoa 80-100 km/o da. Baina automobilaren erabilera hazi da -ikusi dugunez- eremu urbanoan eta abiadura handiko errepideetan. Egindako kilometroen portzentajea txikiagoa dela ere, isurketa hazkorra da, gidatzeko ohiturei lotutako bi arrazoirengatik: hiriko eta hiriarteko mugikortasunaren motorizazio hazkorra (errejimen optimoaren azpikoa) eta autopista-sareen handitzea eta ibilgailuen potentzia (errejimen optimoaren gainetikoa). Guztiarekin, egindako kilometro bakoitzeko bataz besteko kontsumoa gero eta handiagoa da. 
Honi, bide batez, garraiorako erabilitako energia-motei lotuta, bi zehaztapen erantsi ahal dizkiogu: batetik, garraioa da gasolinaren eta gasoilaren kontsumitzaile nagusia; bestetik, erregai horiexek dira kutsakorrenak.

Aldaketa klimatikoari erreferentzia eginez gero, negutegi efektuko gasen isurketari dagokionean, garraio sektoreko emisioen \%96 errepideko garraioak eragiten du, eta \%60 da turismoek eragindakoa. Aldiro nabarmentzen ari naizenez, turismo modura, eta oro har garraio modura, ziklo globala kontsideratuz gero, datu absolutuak errebisatu beharrean geundeke.

\section{ESPAZIOA ETA INGURUMEN INPAKTUAK}

Ziklo globalaren ikuspegiak, hirugarrenik, arreta berezia ipini behar die espazioari eta ingurumen inpaktuei. Dagoeneko iradoki ditut hainbat adierazle eta datu. Guztiarekin, azpiegiturek, eta tartean garraioei loturikoek, azken urteotan hainbat ondorio izan dituzte: errepide proiektuak gain-dimentsionatu egin dira, diseinuaren parametroak hazi dira, obren kosteak joera hazkorra izan du, eta funtsean lurraldearen kontsumoa eta ingurumen inpaktua ere hazi egin da.

Bestalde, aipatuta utzi behar da abiadurari estuki lotuta daudela bide segurtasuna, ingurumen inpaktua, zarata edota ibilgailuen bizitza.

Azkenik, lurzoruaren okupazioarekin eta lurraldearen antolaketarekin, inpaktua ez ezik, azpiegiturek eragiten dituzte garrantzi ekologiko eta paisajistikoa duen inguruen degradazioa, zoruaren asfaltizazioa eta beraz gaitasun produktiboaren galera. Hau guztia ere aintza hartu beharko genuke, automobil pribatuaren eboluzioa eta ingurumen inpaktua aztertzerako orduan. Gera bitez, behintzat, ideiak zerrendatuta.

\section{EZTABAIDA}

Garraioaren sektorea da gobernuetako ingurumen sailetan buruhauste gehien eragiten ari dena. Maila lokalean eta globalean antzematen dira garraio-sistemaren eta mugikortasun motorizatuaren inplikazioak. Izan ere, azken urteotako datu estatistikoak eta ingurumen inpaktuak sektoreka eta aktibitate ekonomikotan alderatuta, garraioaren sektorea da kontsumorako eta emisiorako joera hazkorra aldatu ez duena. Eta horretan automobil pribatua da pisu nabariena duena. Hori gutxi ez eta, automobilaren trakziorako energia-mota finitua eta oso kutsakorra da. Gainera, paradoxikoa iruditu arren, kontsumo energetiko agregatuei arreta ipinita, portzentajezko distribuzioak erakusten digu faktura energetiko globalean ibilgailuen eraikuntzarako fasearen eragina dela hazten ari dena. Idazlanean zehar, emaitza horiek detektatu eta azaldu ditut, besteren artean. 
Idazlaneko emaitzekin agerian geratu da automobil pribaturen joera hazkorra kontsumo energetikoan, emisioetan eta bestelako ingurumen inpaktuetan. Honen harira, hainbat dira gobernuetako ingurumen sailetatik iradokitako programa estrategikoak (lurralde plangintzan, hirigintzan, garraio azpiegituretan eta plangintzan). Eztabaidaren atalean ondokoa planteatzen dut: arazoa ulertu eta aurre egiteko baliatu ohi diren ikuspegi teoriko eta kontzeptualak mugatuak direla eta ikuspegi osatuagoa behar dugula.

\subsection{Ikuspegi kognitiboa, instrumentala eta sozio-teknikoa}

Alde batetik, ikuspuntu kognitiboak eta instrumentalak daude. Ingeniaritzako premisa linealean oinarrituak daude. Honela formulatu genezake: teknika enpirikoak ezagutza praktikoak eta makinak dira; teknologia ezagutza zientifiko aplikatu gisa eta artefaktu industrial modura ulertzen da; garapen teknologikoaren faktore nagusitzat iradokitzen dira ikerketa eta garapen politikak eta berrikuntzaren difusioa; aplikazio teknologikoak eta bere merkaturatzeak aterabidea ekarriko du. Horrek esplikatzen du sarritan politika publikoetatik finantzatu eta bultzatu diren estrategiak, planak eta ekimenak. Ikuspuntu hauen arabera, auziak (garraioa, automobila, ingurumen inpaktua) dimentsio teknikoa du eta soluzioa ere ezagutzan, trebezietan, tresnetan edota teknologian kokatuko litzateke. Azken unean, aldaketa teknologikoaren eta efizientziaren inguruko promesak ere, ikuspuntu horien aldaera gaurkotuak dira.

Aitzitik, sarriegitan planifikazioak mugatuak eta partzialak izan ohi dira, hainbatetan efektu ez-desiragarriak, aurreikusi gabekoak eta kaltegarriak ere eraginaz, idazlanean ikusi dugunez. Horren adibide deigarriena da ondokoa: azken urteotan efizientzia teknikoan, automobilaren berrikuntzan eta planifikazio energetikoan (subentzioak, zerga kenkariak) hainbat urrats eman dira, baina, hala ere, automobilen funtzionamendurako input, output eta ingurumen inpaktuak handitu egin dira. Jite oso diferenteko adibidea da automobilaren segurtasunari dagokiona. Ikerketek erakutsi dute (Adams 2006) segurtasuneko berrikuntzak (disko-balaztak) edota segurtasun-gerrikoei buruzko legeak hainbatetan istripurako joera indartzen duela, baldin eta, gidariaren portaera arriskutsuagoa bada, teknologiek segurtasun-sentsazioa eraginda. Hirugarren adibidea da auto elektrikoek gure herri eta hirietan izan duten ibilbide kamutsa.

Beste era batera esanda, adibide hauek iradokitzen digute kultura teknologikoen (automobilaren) anbiguotasuna, testuinguruarekiko dependentzia, faktoreen arteko elkarmenpekotasuna edota izaera konplexua. Zentzu honetan, zaurgarritasuna metafora baliatu genezake (Hommels et al 2014). Alde batetik, kulturak eta gizarteak teknologikoarekiko zaurgarriak dira. Esate baterako, automobil pribatuak eta garraioak ingurumen arazoak eragin dituzte, edota gure bizitza-estiloak mugikortasun motorizatuari erabat baldintzatuak daude. Bestetik, ordea, teknologiak gizartearekiko eta kulturarekiko zaurgarriak ere badira. Esate baterako, teknologia egingarriak eta bideragarriak gizarteak blokeatu ditzake, besteren artean, teknologiarekiko interes faltagatik, errentagarritasun ezagatik, 
oposizio sozialagatik, edota azpiegituren eta ohituren eskasiagatik. Nekazaritzako elikagaien bioteknologiak erakutsi digu teknologia egingarriak oposizio sozialagatik merkaturatu gabe geratu daitezkeela, edota auto elektrikoaren ibilbide kamutsak erakusten digu artefaktuaren (auto elektrikoaren) bideragarritasuna egonkortzeko ez direla aski sistemaren dimentsio teknikoak (aurrerapen teknikoak) eta ostera bestelako dimentsioak eta azpiegiturak ere behar izaten direla. Ildo beretik, automobilaren bilakaerak erakusten digu automobilaren berrikuntza eta efizientzia teknikoa ez direla nahikoa, ingurumen inpaktua leuntzeko, aski baita ohitura berriak eta portaera sozialak sendotzea (motorizazio indizea, automobil parkearen berritze intentsitatea, ibilgailuen tamaina), traiektoria sendotzeko. ${ }^{4}$

Adibide hauek guztiek, era batera edo bestera, gaiaren konplexutasuna eta dimentsioen ugaritasuna iradokitzen dute. Izan ere, artefaktu edota sistema orok ditu dimentsio teknikoa, soziala edota kulturala. Hori da hurrengo bi azpi-ataletan argitzen saiatuko naizena.

\subsection{Automobila: osagai heterogeneoko sistema}

Automobila ere sistema sozio-tekniko modura ulertu behar dugu, alegia, praxia errealean elkarri elikatzen dira instituzioak, publizitatea, teknologia, produkzioa, banaketa, kontsumoaren kultura edota herritarren behar instrumentalak eta adierazkorrak, besteren artean (Shove et al., 2015; Urry, 2013).

Osagai horien guztien garrantziaz ohartzeko, ipin diezaiogun mugikortasunaren eboluzioari arreta. Azken hamarkadetan mugikortasunaren motorizazioa gertatu bada, eta automobila ezinbesteko beharra bilakatu bazaigu, faktore ugari eta osagarriren ondorioz gertatu da. Hasteko eta behin, errepide sareetan eta beste azpiegituretan inbertsio masiboak egin dira. Bestetik, masa produkzioa eta hedaduraz erabileraren eta mantenuaren kostuen merkatzea eman dira; automobilaren industria, konponketa tailerra eta beste zerbitzu osagarriak egonkortuta. Era berean, petrolioa eta bere ezaugarriak ere funtsezkoak gertatu dira: dentsitate energetiko altukoa, manipulazio errazekoa, erabilera anitzekoa eta bolumen handikoa, eta prezio baxukoa. Gainera, produkzio, erosketa eta erabilera erraztasunak ez ezik, izaera sozial eta kulturaleko berezitasunak ere baditu (distantzien eta lekualdatzeko denboren murriztea, erosotasuna, askatasuna), bereziki, modernizazioaren hastapenetan. Hori gutxi ez eta, automobilarekin geografia, ekonomia edota harreman sozialak ikaragarri eraldatu dira. Neurri berean, giza harremanak biziagotu, estimuluak biderkatu eta aisialdirako gogo, aukera eta beharrak areagotu ditu.

\footnotetext{
${ }^{4}$ Bide batez, efizientzia teknikoaren mugak aspaldi formula batek aise ondo esplikatuta utzi ditu. Giza inpaktu agregatuen magnitudea biosferan neurtzeko, biztanleria, kontsumituriko ondasun kantitatea eta teknologia ebaluatzen dira. J.P. Holdren eta P. Elrichek (1974) hedatu zuten ingurumen inpaktua neurtzeko formula: II [ingurumen inpaktua] $=\mathrm{D}$ [Demografia] $\times \mathrm{T}$ [Teknologia mota] $\times$ bbK [bataz besteko Kontsumoa].Honela neurtuko genuke efizientziaren hobekuntza eta ingurumen inpaktu agregatuen harremana. Zentzu honetan, efizientzia ekologikoa da zerbitzu optimoa (asebetetze maximoa) energia eta materiaren kontsumo eta emisio fluxu minimoekin lortzea.
} 
Gaiak ertz gehiago ditu, baina horiek aski dira, hemen planteatu nahi dudana aditzera emateko.

Zentzu honetan, teknologia, eta zehazki automobil pribatua, oso bestela kontzeptualizatu eta ulertu behar ditugu. Irakurketa sistemikoan analisi unitateak konplexuagoak dira (artefaktu sistemak, materialak, energia, industria, erabiltzaileak, aseguru-etxeak), teknologiak izaera sistemikoa du, eta garapenaren faktore nagusia berrikuntza soziala eta kulturala dira. Alegia, sistema hainbat faktorek eratzen dute: lehengaiak eta energia; osagai materialak; elementu intentzionalak (ezagutzak, gaitasunak, balioak) eta agenteak (industria, erabiltzaileak, kudeatzaileak); sistemaren egitura (prozesu fisikoak, kudeaketa harremanak, legedia eta erregulazioa, monitorizazioa); helburuak; emaitzak (nahitakoak, gogokoak, ez aurreikusiak, kaltegarriak, nahigabekoak). Europako hainbat proiektu, diseinu eta ekintza-planetan ikuspegi sistemikoaren kontzientzia ernaltzen ari da.

Hori dela eta, beste hainbat sektore eta aktibitate ekonomikotan bezala, garraioaren eta automobil pribatuaren erabilera doitzeko xedeak ere, sistemaren dimentsio fisikoak, teknikoak eta sozialak aintzat hartu behar ditu, hala nola: automobilaren industria (merkatu mundiala, egitura produktiboak, sare komertzialak); bizitza estiloen modernizazioa eta masa kontsumoa; publizitatea eta adin zein status sozio-ekonomiko desberdinen kontsumitzeko gaitasuna eta kultura: handikeriak, imitazioak edota inertziak hartara bultzatuta; garraio mekanikoarekin espazioa eta denbora itxuraldatzea; giza jardueren disoziazio espaziala (bereizi egin ditu habitata, lantokia, komertzio minorista, dibertsiorako eta bizitza kulturalerako guneak); desplazamenduaren eta garraioren beharra (mugikortasun obligatua). Gauzak horrela, maila analitikoan bereizi ahal ditugu dimentsio fisikoa, teknikoa, soziala edota kulturala, baina praxia errealean dimentsio horien artean konkurrentziak, erresistentziak, kontradikzioak eta tentsioak azaleratzen dira. Ikuspegi sozio-teknikoak, beraz, balio digu lehen zehaztapena egiteko: garraioa eta automobila ulertu behar ditugu osagai heterogeneoko sistema modura.

\subsection{Automobila: traiektoria egonkortua}

Ikuspegi sozio-teknikoak, ordea, balio digu bigarren zehaztapen inportantea egiteko. Esan bezala, sistema osagai teknikoek eta humanoek osatzen dute. Baina hauen arteko artikulazioekin erronka teknikoak, politikoak edota ekonomikoak ebatzi ahala, sistema sozio-teknikoek autonomia eta bulkada (momentum) zehatza hartzen dute; pixkanaka malgutasuna galdu, zurrundu eta agente humanoen askatasun-gradua murrizten da (Hughes 2004). Bestela esanda, automobilak traiektoria sendotu eta egonkortu ahala, osagai fisiko, tekniko eta sozialen garrantzia erlatiboa aldatu egiten da. Zehaztapen hau ere erabakigarria da, gaur egunean automobil pribatuak hartuak dituen inertziak eta nagusitasuna ulertu ahal izateko.

Autonomia, bulkada eta traiektoria zehatza hiru propietaterekin gauzatzen da: masa (egitura eta artefaktu fisikoek konfiguratzen dute, agi denez pertsonen ezagutzak, interesek 
eta baliabideek hala eraginda), abiadura eta norabidea (masa sendotu ahala, sistemak abiadura eta norabide jakina hartzen ditu). Bigarren zehaztapena oso inportantea da. Sistemak bulkada izan ahala, autonomia hartzen du; esan bezala, nolakotasun sozio-teknikoa duen arren. Beste hitzetan esateko, teknologiaren garapen dinamikoan heltzen da momentu bat (heldutasuna) sistemari zaila egiten zaiona berrikuntza teknikoak eta sozialak bere gain hartzea. Are gehiago, teknologiak izaera sozio-teknikoa badu, hori bezain garrantzitsua da ohartzea aldaketa eta berrikuntza teknologikoak ere paper erabakigarria duela ingurunearen eta honen dinamiken baldintzatzean. Automobila egoera horretan dago: heldutasun eta egonkortze unera iritsita, sistemaren osagaiak zurrunduta daude, kosta egiten da osagaiak eta hauen arteko elkarreraginak modu diferentean artikulatzea, baina gainera automobilaren ingurune osoa (azpiegiturak, lurraldearen antolaketa, aisialdia, bizitzeko modua) ere bere beharretara moldatua dago; automobilak izaera performatiboa du. ${ }^{5}$

Hori dela eta, automobil pribatuaren egonkortzearekin, planifikazioak eta ingeniaritzak ere eredu konbentzionala elikatzen du (ikus 11. taula): garraioaren dimentsio fisikoa hobesten du; mugikortasunean oinarriturikoa da; trafikoan eta honen gestioan fokatzen da; eskala handikoa da; ingurua (kalea, bidea) errepidearen begiradatik antolatzen da; garraio motorizatua da erdigunea; aurreikuspen eta prospekzioek trafikoa, eskaria, abiaduraren bizkortzea eta denboraren minimizazioa dituzte ipar; aukeren ebaluazioak izaera teknikoa eta ekonomikoa du; eta, funtsean, trafikoaren eta pertsonen segregazioa elikatzen du.

Bi zehaztapenak oso dira inportanteak: alde batetik, gizartearen eta teknologien artean elkarrenganako eragina ematen da (automobilaren izaera sozio-teknikoa); baina, bestetik, osagaien arteko korrelazioa aldatu egiten da, eta sistemaren eboluzioarekin, traiektoria egonkortu eta osagaien arteko simetria galdu egiten da (osagai teknikoen nagusitasuna).

Automobilaren kasuan, ikuspegi sozio-teknikoak erabateko balioa du. xx. mendearen hastapenetatik automobilaren eboluzioa aztertzen badugu, antzemango dugu hasierako malgutasuna diseinuan, erabileran eta energia-iturrietan (lurruna, elektrizitatea, barneerrekuntza) pixkanaka galduko egingo dela, bulkada gertatu ahala; bulkada emango da artefaktua bizitza pertsonaletan, ekonomian, balioetan edota hiri planifikazioetan atrintxeratu ahala; osagaien arteko simetria eta malgutasuna galdu ahala. Egiaz, lehen une batean, automobilaren konfigurazioan testuinguru historikoa garrantzitsua da (automobilak gurdien antza izango du eta «zaldirik gabeko gurdia» deituko zaio), baina ibilian-ibilian dinamika autonomoa hartu eta testuingurua eraldatzea eragin du. Testuinguru hori osatzen duten osagaien artean daude: hornitegiak, konponketarako tailerrak, trafiko arauak, erre-

\footnotetext{
${ }^{5}$ Urryk (2006: 27) honela dio: «Automobility can be conceptualized as a self-organizing autopoietic, non-linear system that spreads world-wide, and include cars, car-drivers, roads, petroleum supplies and many novel objects, technologies and signs. The system generates the preconditions for its own self-expansion».
} 
pide eta autopistak, manufaktura eta herri-lanetako enpresak, akzio karterak, eta abar. Automobila artefaktu fisikoa ez ezik, sistema sozio-teknikoaren parte ere bada; eta, gero eta modu nabariagoan, automobilak baldintzatzen du sistema sozio-teknikoa (Paterson, 2007; Rajan, 2006).

Esandakoaren osagarri modura, hautemate sozialetan, garraioaren eta garraio-azpiegituren etorkizunaz galdetuta, emaitza deigarriak topatzen dira. Herritarrek aurreikusten dituzte zientziaren eta berrikuntza teknologikoaren inpaktu positiboak, baina zalantza nabariagoa da pertsonen ekintzei eta portaerei buruz galdetuta. ${ }^{6}$ Era berean, berrikuntzei buruz galdetuta, asoziazioak adibide hauekin egiten dira: ABS eta air baga, errepide hobeak, hirietako tramo hobeak. Bestalde, etorkizun hurbileko inpaktu positiboei eta negatiboei buruz galdetuta ere, inpaktu positiboen artean baloratu eta aurreikusten dira garraio-azpiegitura hobeak (errepideak, zubiak, tunelak) eta denboraren murriztea, autoen segurtasuna, GPS nabigazio-sistema, eta garraio publikorako aukera hobeak eta auto elektrikoak. Ostera, inpaktu negatibo modura, poluzioaren hazkundea iragartzen da. ${ }^{7}$ Etorkizunari buruzko hautemate sozial horiek ondo ezkontzen dira hemen azpimarraturiko ikuspegi eta joerekin: aurrerapen teknikoak emango dira, baina ez da aurreikusten (uneotan, hautemate sozialetan) traiektoriaren aldatzea eta mugikortasun jasangarrirako aukera.

\subsection{Mugikortasun jasangarria}

Guztiarekin, eztabaidan, beraz, bi zehaztapen garrantzitsu iradoki ditugu. Analisia, ordea, partziala egingo dugu, automobil-sistema bakarra aintzat hartuz gero. Izan ere, bestelako aukerak ere badira: mugikortasun errejimenak aldakorrak dira eta, motorizazioarekin batera, garraio aktiboa (oinezkoa, bizikleta) edota garraio publikoa sustatzen duten herriak eta hiriak ere badira.

Honek mugikortasunaren inguruko alternatiba teorikoak eta kontzeptualak ere iragartzen ditu (Böhm et al., 2006; Cresswell, 2010). Kasu hauetan, ikuspegi alternatiboak mugikortasun jasangarria hobesten du (ikus 11. taula): dimentsio soziala hobesten du; irisgarritasunean oinarriturikoa da; pertsonetan fokatzen da, dela garraioa dela oinezkoa arreta-gunea; eskala lokalekoa da; ingurua (kalea, bidea) espazioaren begiradatik antolatzen da; garraioak hierarkizatzen ditu eta oinezkoak eta bizikletak lehenetsi; aurreikuspen eta prospekzioek hiria, kudeaketa, abiaduraren moteltzea eta denbora zentzuzkoa dituzte ipar; aukeren ebaluazioak irizpide ugari ditu eta kezka ekologikoak eta sozialak aintzat hartzen ditu; eta, funtsean, trafikoaren eta pertsonen integrazioa elikatzen du.

\footnotetext{
${ }^{6}$ EC (2014): Public perceptions of science, research and innovation. Special Eurobarometer 419. European Union, 79-84 or.

${ }^{7}$ EC (2015): Public opinión on future innovations, science and technology. Eurobarometer Qualitative study, Aggregate Report. European Union, 11 eta 29 or.
} 
11. Taula. Garraioaren planifikazioa

\begin{tabular}{|c|c|}
\hline $\begin{array}{l}\text { Ikuspegi konbentzionala: } \\
\text { Garraioaren planifikazioa eta ingeniaritza }\end{array}$ & $\begin{array}{l}\text { Ikuspegi alternatibo bat: } \\
\text { Mugikortasun jasangarria }\end{array}$ \\
\hline $\begin{array}{l}\text { Garraioaren dimentsio fisikoa hobesten du; } \\
\text { Mugikortasunean oinarriturikoa da; } \\
\text { Trafikoan eta honen gestioan fokatzen da; } \\
\text { Eskala handikoa da; } \\
\text { Ingurua (kalea, bidea) errepidearen begiradatik } \\
\quad \text { antolatzen da; } \\
\text { Garraio motorizatua da erdigunea; } \\
\text { Aurreikuspen eta prospekzioek trafikoa, eska- } \\
\text { ria, abiaduraren bizkortzea eta denboraren } \\
\text { minimizazioa dituzte ipar; } \\
\text { Aukeren ebaluazioak izaera teknikoa eta eko- } \\
\text { nomikoa du; } \\
\text { Trafikoaren eta pertsonen segregazioa elika- } \\
\text { tzen du. }\end{array}$ & $\begin{array}{l}\text { Dimentsio soziala hobesten du; } \\
\text { Irisgarritasunean oinarriturikoa da; } \\
\text { Pertsonetan fokatzen da; } \\
\text { Eskala lokalekoa da; } \\
\text { Ingurua (kalea, bidea) espazioaren begiradatik } \\
\text { antolatzen da; } \\
\text { Garraioak hierarkizatzen ditu eta oinezkoak eta } \\
\text { bizikletak lehenetsi; } \\
\text { Aurreikuspen eta prospekzioek hiria, kudea- } \\
\text { keta, abiaduraren moteltzea eta denbora } \\
\text { zentzuzkoa dituzte ipar; } \\
\text { Aukeren ebaluazioak irizpide ugari ditu eta } \\
\text { kezka ekologikoak eta sozialak aintzat har- } \\
\text { tzen ditu; } \\
\text { Trafikoaren eta pertsonen integrazioa elikatzen } \\
\text { du. }\end{array}$ \\
\hline
\end{tabular}

Iturria: Aldred 2014 (Jatorriko egilea: D. Banister).

Garraioaren planifikazioa ulertzeko bi paradigmen alderatzeak balio digu ohartzeko badirela aukera teoriko eta praktikoak automobilaren traiektorian eragiteko. Halere, mugikortasun jasangarriaren proposamena ez da hutsean gertatzen, noski. Testuinguru orokorrago batean kokatuz gero, bere zailtasunak agerikoak dira, une hauetan bederen, automobilaren sistemak osagai sendoak baititu, traiektoria, direkzio eta konfigurazio sozio-teknikoa egonkortzen dutenak (Rip eta Kemp 1998; Voss et al 2006), orobat, automobilaren erregimena. Era berean, paradigma alternatiboaren irismena ere, neurri berezian, eremu lokalekoa eta eskualdekoa da, eta hori dinamika globalen testuinguru orokorrean eremu mugatua da. Komeni da paradigma alternatiboaren muga horiek gomutan izatea. Guztiarekin, mugikortasun jasangarriaren inguruko lan teoriko eta praktikoak erakusten digu bestelako aukerak egingarriak eta bideragarriak direla.

\section{HAINBAT ONDORIO NAGUSI}

Idazlanaren helburu orokorra izan da automobil pribatuaren bilakaerak ingurumenean duen inpaktua ulertzea. Izan ere, azken urteotan automobilaren ingurumen inpaktuaren inguruko kezka areagotu egin da. Emaitzen atalean horren berri eman dugu. Baina idazlana ez da mugatu azalpen estatistikoa eta deskriptiboa egitera. Hipotesia izan da automobila kontzeptualizatzeko marko analitiko mugatua dugula eta horrek zaildu egiten duela automobilaren traiektoria aldatzea. Hori dela eta, idazlanean proposatu dut ikuspegi so- 
zio-teknikoa eta balio izan digu automobilaren dimentsioen ugaritasuna detektatzeko eta dinamika garaikideak ulertzeko. Garraioaren eta mugikortasunaren inguruko politika publikoak diseinatzerakoan, ezinbestekoa da dimentsioen ugaritasuna eta horien arteko elkarmenpekotasuna planifikazioan egoki integratzea, beraz.

Hasteko eta behin, automobila ez da artefaktu tekniko hutsa eta testuinguru sozialetik at ulertu daitekeena, baizik eta automobila sistema heterogeneoa da, hainbat aldagai eta dimentsioren arteko erlazioan hartzen ditu forma eta traiektoria zehatza, eta une hauetan, automobilaren erregimen sozio-teknikoa egonkorra eta zurruna da. Ikuspuntu sistemikoa proposatu eta automobilaren izaera sozio-teknikoa argitu dut. Honek balio izan digu automobilaren sistema nola egonkortu den ulertu eta automobilaren traiektoria aldatzeko dauden zailtasunak esplikatzeko. Izan ere, plangintzak oro har ingeniarien premisa tekniko eta linealetan oinarritzen dira, baina automobilaren sistema osagai teknikoek ez ezik beste hainbat osagaiek ere osatzen dute. Horien artean gainera elkarmenpekotasuna dago eta hainbatetan berrikuntza teknologikoen balioa lausotuta geratzen da. Esate baterako, idazlanaren atal deskriptiboan ikusi dugu automobilaren efizientzia teknikoa nabarmen garatu dela, baina, hala ere, automobilaren trakzioaren kontsumo eta emisio energetikoa hazi egin dela, besteak beste, bizitza-ohiturei loturiko arrazoiengatik (motorizazio indizea, automobil parkearen berritze intentsitatea, ibilgailuen tamaina). Ikuspegi sozio-teknikoak balio digu automobila sistema heterogeneo, konplexu eta erlazional modura ulertzeko. Automobilaren sistema osatzen duten osagai teknikoei, fisikoei, sozialei eta kulturalei estuki lotuta ulertzen dugu automobilaren ingurumen inpaktua. Neurri horretan, automobilaren traiektoria aldatzeko zailtasunak eta garraio jasangarria mataza beraren hariak dira.

Automobil pribatuarekin igartzen den porrota, neurri batean, haren izaera ulertzeko modu partzialak (erredukzionismo teknikoa) esplikatzen du. Aitzitik, erronkaren izaera soziala eta organizaziokoa ondo antzematea baldintza da, arazoaren definizioa egoki egin, osagai sozio-teknikoen garrantzia planteatu eta sistemaren traiektoria aldatzeko. ${ }^{8}$

Guztiarekin, idazlanak bi muga nagusi ditu eta etorkizuneko helburu eta zereginetan integratu egingo ditugu. Lehen muga ziklo globalaren metodologiak esplikatzen digu. Izan ere, emaitzen atala nagusiki automobilaren trakzioak eragindako kontsumo eta emisio energetikoa aztertzera mugatu dut. Honi lotuta, ziklo globalak erakusten digu ez soilik ertz gehiago daudela (automobilaren eraikuntza, azpiegituren eraikuntza, zirkulazioa, garraiosistemaren mantenua, hondakinen eliminazioa edo gestio, horren guztiaren ingurumen inpaktua), baizik eta hori gainera planetaren eremu osoa aintzat hartuta osatu behar dela, baliabide naturalen eta energiaren fluxua (automobilaren metabolismoa) ezagutuko bada. Azken hau egoki ulertzeko, aski da Pasaiako edo Bilboko portuan geldiunea egitea, eta

\footnotetext{
${ }^{8}$ Bide batez, artikuluan automobilaren kasua izan dugu aztergai, baina eraldaketa askotarikoak beharko dira, gizateria Lurra planetan modu jasangarrian biziko bada. Erronka bideratzeko moduei buruz eta aliantzen inguruan, ikus Scoones et al. 2015.
} 
ohartuko gara, esaterako, zer nolako garrantzia eta inpaktua duten erregai solidoen inportazioak edota kotxeen esportazioak (bi portu horietatik ateratzen dira Españako hainbat tokitan egindako kotxeak, bide batez, errepidez eta trenbidez portura garraiatu beharrak daudenak). Ekoizpen, banaketa eta komertzializazio sareak mundialak diren heinean, automobilaren metabolismoa ulertzeko ezinbestekoa izango da ziklo integralaren analisiak dinamika global horiek jasotzea.

Bigarren muga gaia bera da. Idazlanaren gaia izan da automobila eta ingurumen inpaktua. Agi denez, ingurumena auzi inportantea da, baina partziala, eta gainera ingurumena testuinguru dinamiko eta kontingente batean ulertu behar dugu. Adibidez, garraioaren sektorea, EAEn, baita mundu mailan ere, lehiakortasunaren, hazkunde ekonomikoaren, enpleguaren, aktibitate okupazionalaren eragilea da. Automozioaren euskal industria sendoa da. Esaterako, Acicae clusterrari asoziaturiko enpresek 2015.urtean 15.004 milioi euroko fakturazioa («errekor historikoa») izan dute; sektorearen fakturazioaren \%90 esportazioari dago lotuta; EAEko plantetan 36.583 langile daude eta atzerrian 40.000 langile ari dira; automobilaren sektoreak EAEko BPGren \%22 suposatzen du. Dinamika horiek ere ezinbestean analisi soziologikoak jaso behar ditu, aukerak eta erronkak egoki diseinatu eta hausnartzeko. Beste hitzetan esateko, automobilari, garraioari eta mugikortasunari buruzko tentsioak eta kontradikzioak modu integralean aztertu beharko ditugu.

Horren osagarri, adibide zehatzak ere jarri daitezke. ${ }^{9}$ EAEn autogintzako osagaien hornitzaileak dauzkagu eta arlo horretan euskal industriak mundu mailako pisua du (CIE Automotiv taldea, GESTAMP taldea, Mondragon taldeko hainbat kooperatiba); makina tresneriako industrian (Espainia da arlo horretako zortzigarren indarra eta EAE da industriaren \%85 hartzen duena) zati inportantea autogintzan ari da lanean; gurpilgileak (Michelin) eta beiragileak (Vidraia, Gurdian) ere industria sendoa dira; baditugu askotariko zerbitzuak eskaintzen dituzten erakundeak eta enpresak (finantza-erakundeak, aseguru-etxeak, aholkularitza-enpresak, besteak beste), baita ere formazio zuzena eta zehatza eskaintzen dutenak (zentro teknologikoak, lanbide heziketako ikastetxeak, unibertsitateak). Gaur egunean ere, agerikoak dira indar korrelazioak eta interesak automobilaren traiektoria indartu eta biziagotzen dutenak.

Lehen mugak iradoki badigu lurra planeta aintzat hartzearen premia, bigarren mugak erakusten digu maila lokaleko analisietan dimentsio ekologikoa ez ezik bestelako dimentsioak ere kontsideratu beharko ditugula, mugikortasunaren inguruko dinamikak, tentsioak eta kontradikzioak ulertuko baditugu. Guztiarekin, idazlanak erakutsi du horiek guztiek ingurumen inpaktua eragiten dutela.

Horiek adibide batzuk dira. Ikuspegi sozio-teknikoak horiek ez ezik bestelako osagai teknikoak, fisikoak, sozialak eta kulturalak ere balioan jartzea proposatzen du, eztabaida-

\footnotetext{
9 Ebaluatzaileetako bati eskertzen diot aipamena. Iruditzen zait, ondo ilustratzen duela iradokitzen dudana, eta hona ekarri dut.
} 
ren atalean landu dugun moduan. Horregatik deritzot ekarpena ikuspegi sozio-teknikoari, automobilaren sistema, honen egonkortzea, traiektoria aldatzeko zailtasuna, edota ingurumen inpaktua ulertzeko marko analitiko egokia eskaintzen digulako. Neurri berean, ikuspegi sozio-teknikoak hainbat pista ematen dizkigu, bestelako traiektoriak (garraio jasangarria) irudikatzeko.

\section{REFERENCIAS BIBLIOGRÁFICAS}

Adams, J.(2006) The Failure of Seat-Belt Legislation in Marco Verweij eta Mary Thompson (arg.) Clumsy Solutions for a Complex World, Houndmills, UK: Palgrave Macmillan, 132-154 or.

Aldred, R.(2014) The New Mobilities Paradigm and Sustainable Transport: Finding Synergies and Creating New Methods in Stewart Lockie, David A. Sonnenfeld eta Dana R. Fisher (arg.) Routledge International Handbook of Social and Environmental Change, London, Routledge, 190-203 or.

Banister, D.(2008) The Sustainable Mobility Paradigm Transport Policy, 15. lib., 2. zk., 7380 or.

Bell, D. (1973) The Coming of the Post-Industrial Society, New York, Basic Books.

Böhm, Steffen, Campbell Jones, Chris Land eta Matthew Paterson (arg.) (2006) Against Automobility, Oxford, UK, Blackwell.

Cresswell, T. (2010) Towards A Politics of Mobility Environment and Planning D: Society and Space, 28. lib., 7-31 or.

Estevan, A. (1993) Análisis de externalidades y condicionantes de la competitividad por modos de transporte, Madrid, Ministerio de Obras Públicas, Transportes y Medio Ambiente.

Estevan, A. (2004) Externalidades del transporte: modelo de evaluación, Madrid, Ministerio de Fomento.

Featherstone, M., Nigel T. eta Urry, J. (arg.) (2005) Automobilities, London, Sage Publications.

Gorz, A. (1975) Écologie et politique, Paris, Galilée.

Healy, H., Martínez-Alier, J., Temper, L., Walter, M. eta Gerber J.F. (arg.) (2013) Ecological Economics from the Ground Up, London, Routledge. 
Holdren, Jo. H. eta Ehrlich, P.R. (1974) Human Population and the Global Environment American Scientist, 62. lib., 282-292 or.

Hommels, A., Mesman, J. eta Bijker, W.E. (arg.) (2014) Vulnerability in Technological Cultures: New Directions in Research and Governance, Cambridge, The MIT Press.

Hughes, T. P. (2004) Human Built World: How to Think about Technology and Culture, Chicago, University of Chicago Press.

Illich, I. (1974) Ecology and Equity, London, Calder and Boyers.

Lefebvre, H. (2008) Critique of Everyday Life, vol. 2, Foundations for a Sociology of the Everyday, London, Verso.

Marshall, S. (2001) The Challenge of Sustainable Transport in Antonia Layard, Simin Davoud eta Susan Batty (arg.) Planning for a Sustainable Future, London, Spon Press, 131-147 or.

Paterson, M. (2007) Automobiles Politics: Ecology and Cultural Political Economy, Cambridge, Cambridge University Press.

Rajan, S. (2006) The Enigma of Automobility: Democratic Politics and Pollution Control, Pittsburgh, PN, University of Pittsburgh Press.

Rip, A. eta Kemp, R. (1998) Technological Change in Steve Rayner eta Liz Malone (arg.) Human Choice and Climate Change (vol. 2), Columbus, OH: Battelle Press, 327-399.

Scoones, I., Leach, M., eta Newell, P. (arg.) (2015) The Politics of Green Transformations, New York, Routledge.

Shove, E., Watson, M. eta Spurling, N. (2015) Conceptualizing connections: Energy demand, infrastructures and social practices European Journal of Social Theory, 18. lib., 3. zk., 274-287 or.

Smith, M.R. eta Marx, L. (arg.) (1994) Does Technology Drive History? The Dilemma of Technological Determinism, Cambridge, MIT Press.

Urry, J. (2006) The System of Automobilty Theory, Culture and Society, 21. lib. 4-5 zk., 2539 or.

Urry, J. (2013) Societies beyond Oil: Oil Dregs and Social Futures, London, Zed Books.

Voss, J. P., Bauknecht, D. eta Kemp, R. (arg.) (2006) Reflexive Governance for Sustainable Development, Cheltenham, UK, Edward Edgar Publishing Limited. 